Citation: Blum, N. (2008) Ethnography and environmental education: understanding the relationships between schools and communities in Costa Rica. Ethnography and Education, 3(1): 33-48.

\title{
Ethnography and Environmental Education: Understanding the Relationships Between Schools and Communities in Costa Rica
}

Nicole Blum

Institute of Education, University of London

\section{Introduction}

Environmental education has been at the centre of international and national policies of sustainable development for the last several decades, and has stimulated significant debate regarding both its inclusion in curricula and proposed methods for its implementation. Academic writing on the subject has explored the concept's theoretical and conceptual underpinnings (Palmer 1998, Stables 2001) as well as issues of its implementation - including teaching methods (Gough 1996), learner identities (Dillon et al 1999, Palmer et al 1999), teacher training (Jaritz 1996), and the relationships between environmental learning and behavioural change (CourtenayHall \& Rogers 2002, Kollmuss \& Agyeman 2002). This rapidly growing body of research has also sought to assess the practices and potentials of environmental education in a variety of geographical locations and social contexts. Influential research communities in the UK, Australia, and Canada, in particular, have provided the bulk of analytical and case study material within the existing literature.

The more recent international attention given to the links between education and sustainable environmental management and development, specifically through international initiatives such as Agenda 21, however, has inspired a rapid increase in the implementation of environmental education policies and programmes around the world. Partly in response to this, the geographical coverage of existing research has similarly expanded (González Gaudiano 1999, Pellegrini Blanco 2002, Lozt-Sisitka 2004, Kwan \& Lidstone 1998). Much of the research, however, has continued to be conducted with a somewhat narrow focus - for example, on specific curricula and policies or on activities within strictly delineated sites such as schools, classrooms or nature areas. While this work is fundamentally important, what is still largely missing from the literature is attention to the ways in which meanings and understandings of 'environmental education' are altered, contested and/or accepted in diverse contexts, and how these engagements are embedded within multiple layers of interactions between educators, students, schools, communities and nations.

This research therefore used an ethnographic approach to explore the ways in which environmental education programming is negotiated and practised by state and private school teachers in a rural community in Costa Rica. As the following case studies of two schools - one state and one privately-funded - illustrate, while teachers in different kinds of schools face a number of similar challenges to implementing programming, they also both benefit from and are limited in their work by the social and economic positionings of their schools within the community as a whole. For example, while teachers in both schools struggled with a lack of appropriate resources and the demands of the national curriculum and system of assessment, the social and economic positioning of each school (in relation to student population, internal understandings of and commitments to environmental learning, relationships to other local organisations, and language of instruction) both ameliorated some of these problems and also posed further challenges. This suggests that research which looks beyond singular projects and sites - and specifically research which uses ethnographic 
Citation: Blum, N. (2008) Ethnography and environmental education: understanding the relationships between schools and communities in Costa Rica. Ethnography and Education, 3(1): 33-48.

approaches - has the potential to contribute a much deeper understanding of the complex, socially-embedded nature of environmental education.

\section{Environment and Education - A Changing Relationship}

The contemporary environmental education movement arose out of growing concern over the state of the natural world, as well as the growing interest of the international scientific community in ecosystem and species preservation beginning in the 1960s. With its roots in the scientific community, early environmental education relied heavily upon a style of public education and awareness-building that emphasised learning in the natural sciences, and especially in biology, botany and ecology. This emphasis on the promotion of scientific knowledge is clearly evident from the first inter-governmental statement on environmental education, 'The Belgrade Charter - A Global Framework for Environmental Education', which argued that greater knowledge was needed of 'the environment and its associated problems', and focused on raising awareness of environmental damage caused by human activity (UNESCOUNEP 1976). By the 1980s, however, international policy began to more heavily emphasise the links between conservation and development, and the idea of 'sustainable development' became an increasingly important part of development vocabulary. Around the same time, the language surrounding environmental education began to make a similar shift towards greater engagement with the social and economic factors which impact upon environmental management. In 1992, Agenda 21 put education squarely at the centre of discussions of international development by calling for a 'reorientation' of all types of education towards sustainability (UNCED 1992: Section 36.2).

The inclusion of the concept of 'sustainability' in education about the environment has not gone uncontested, however, and numerous terms, definitions and perspectives have since been proposed. In addition to 'environmental education', for example, there are also theories of 'education for sustainable development', 'education for sustainability', 'education for a sustainable future', 'socially-critically environmental education' and 'grass-roots environmental education', each with their own associated histories, goals and advocates (Huckle \& Sterling 1996, Sauvé 1996, Jickling 1992) ${ }^{1}$. At the root of these many different terms and practices is a strong and shared commitment to social change, but debate - among both theorists and practitioners continues regarding which is the most appropriate or effective way to go about achieving it (McKeown \& Hopkins 2003) 2 .

These debates and concerns operate on many levels - internationally and nationally, and also within communities, schools and classrooms. At each level, actors are both supported and constrained by relationships within and among these levels, as well as by the economic and social contexts in which they are located. Teachers, for instance, are variously situated according to their relationships to educational authorities, to

\footnotetext{
${ }^{1}$ While recognising the importance of these many different concepts and the debates which surround them, I use the term 'environmental education' (educación ambiental) here because it is the term most commonly used in Costa Rica where it describes a wide range of types of educational programming about the environment.

${ }^{2}$ Central to these discussions is a fundamental tension between perspectives that emphasise teaching of science concepts (cf. Ham 1992) and those that seek to actively link environmental issues with social ones (cf. Wals 1996, Sterling 2001). I will not address this particular debate here for reasons of space, but have explored it elsewhere (Blum 2006).
} 
particular understandings of the role of environmental education in national development and environmental protection, and also to diverse local perspectives, interests and needs. This research therefore sought to explore the ways in which individual schools and teachers are located within these multiple economic and social relationships has profound impacts on perspectives on, and the implementation of, environmental education policy and programmes.

\section{Research Strategy and Methods}

Exploring such complicated sets of relationships and contexts requires a different approach to research than is commonly found within the existing research literature on environmental education. Ethnographic research, in particular, has the potential to provide a much broader perspective on socially and economically embedded processes of environmental education policy-making and implementation.

In using the term 'ethnographic research', I refer specifically to the anthropological tradition of conducting extended fieldwork and using key methods such as participant observation and interviewing (Hammersley \& Atkinson 1995, Bernard 1988). In less concrete terms, I also refer to the contemporary discipline's practice of following an open and iterative research process, rather than using fieldwork to confirm or deny pre-determined theoretical positions. In this sense, the research was not about building or testing theory about environmental education per se, but rather about exploring the ways in which local actors engage with (i.e. both support and contest) educational programming about the environment, and how these engagements are embedded in the wider social, economic and political dynamics of the community. Examination of these kinds of issues requires an ethnographic approach which allows for extended time in the field in which a researcher can participate in the life of a community, formulate and re-formulate research questions, and have space for on-going discussion with members of the fieldwork community.

Fieldwork was therefore conducted over a one year period (2002-2003) in the Monteverde region of Costa Rica, and was organised around three principal research methods - formal interviews, participant observation and review of archival and grey literature. During that time, I conducted semi-structured interviews with approximately 50 local and national informants, including environmental educators, teachers and administrators in private and state schools, development project coordinators, directors and staff of local NGOs, conservationists and protected area managers, scientists and other researchers, tourism business owners and government officials $^{3}$. In addition, I negotiated collaborative agreements with several classroom teachers and the environmental educators at two local reserves through which I provided support for environmental education programming in exchange for opportunities to observe projects and interact less formally with educators and students. Finally, I also conducted a review of the existing archival material and the extensive body of grey literature produced by local NGOs and relevant government

\footnotetext{
${ }^{3}$ In the following, material taken from these interactions is denoted in one of two styles: direct quotations taken from recorded interview transcripts are placed in inverted commas, and paraphrased passages taken from my interview notes are in italics. Although passages in italics do not represent direct quotations, they are true to the intent of the conversation in which they took place. All translations of interview material and of published resources are mine, and have been noted throughout.
} 
Citation: Blum, N. (2008) Ethnography and environmental education: understanding the relationships between schools and communities in Costa Rica. Ethnography and Education, 3(1): 33-48.

ministries, and academic work by educational researchers and anthropologists at the four national universities.

These methods were not only informative in and of themselves, but were also part of an iterative research process. Although I began with a structured set of questions and issues to explore, I also attempted to remain flexible about any necessary changes or additions to the research plans. Interviews, for example, often generated new questions or issues for observation, and vice versa. In many cases, I supplemented initial, more formal interviews with less formal interaction later, such as at community events or in the course of daily interaction. The archival and grey literature raised a further set of issues about the differences between policy and practice, which I was able to address either in formal interviews or less formal conversation. Throughout the research process, my daily fieldnotes were another, more solitary, place for exploration of the issues raised, and for the development of future questions. In this way, the 'data analysis' was also an integral part of the fieldwork process, rather than constituting a separate stage after leaving the field. Through these multiple levels of interaction and continuing opportunities for discussion over the course of the year, I had the opportunity to gain a broad understanding of local educators' both positive and negative experiences of implementing environmental education programming in local schools, and to explore the complicated ways in which educational practice is situated within local economic and social contexts ${ }^{4}$.

It is worth noting here that in all of these interactions I was keenly aware of my own identity as a researcher and of its potential impacts on the research. As is often the case in highly researched areas of the world, community members in Monteverde are alternately both frustrated and pleased by the amount of attention their home has received since the 1970s. Unfortunately, interactions with previous researchers have not always been positive, and some community members were understandably cautious about taking part in the research. My own nationality (US), gender (female), professional status (PhD student; anthropologist) and language abilities (English and Spanish) undoubtedly had both positive and negative influences on my negotiation of research access to particular organisations and knowledgeable individuals. On the whole, however, I found myself welcomed into a community of active individuals and organisations engaged in intensive debate over the future well-being of their community.

\section{Environmental Education in Costa Rica}

In order to understand some of the dynamics surrounding environmental education in the community itself, it is useful to first understand how it fits within the wider national context. Firstly, education and the environment are both highly politicised areas of national political and economic life in Costa Rica. Education has been important to the national consciousness since the earliest days of the republic, when

\footnotetext{
${ }^{4}$ This iterative process continued in the writing up of the research. Before leaving the community in September 2003, I conducted a public presentation (in Spanish) to ask for feedback on the research process and on some of my preliminary conclusions. This discussion has continued since my departure, with key research participants kindly taking the time to give their comments and suggestions on draft chapters and papers. My thanks, once again, to all those in Monteverde and the Central Valley who have supported the research.
} 
liberal nation-builders emphasised the necessity of providing education in order to encourage national economic development (Fischel Volio 1987). According to one analyst, education has since become so important that it has been granted the status of 'a virtual civil religion, embraced by rulers and citizen alike' (Booth 1998: 94).

The nation's rich and highly biodiverse ecology has also been an area of serious interest - especially for European and North American scientific researchers - since the mid-nineteenth century (Janzen 1983). During the 1970s, both Costa Rican and international scientists became increasingly concerned with the deterioration of the nation's natural areas, and began to campaign for a national system of protected areas. Intensive investment in conservation, education and tourism from both the Costa Rican state and private interests throughout the 1970s and 1980s quickly changed the nation's fortunes. The national park system has since proved to be the foundation of a hugely successful ecotourism industry (Boza 1993, Wallace 1992, Evans 1999), and by 1994, tourism was the nation's biggest foreign capital earner.

Given the economic and social importance of both education and the environment to the nation, it should perhaps not be surprising that environmental education is highly significant to national social and political life as well. Furthermore, it is an area in which the social values promoted in national discourses of education meet with a national drive for the promotion of scientific knowledge for conservation. This convergence is evident, for instance, in publications from the Ministry of Education which call for the promotion of values such as of happiness, tolerance, hope, dialogue, love and peace through education, and require students to be taught about their interdependence on their biophysical, social, economic, political and cultural environments and to participate actively in the detection and solution of environmental problems in their local communities and the rest of the planet (MEP 2002: 19-20). As one Ministry official put it: It isn't like other subjects. It is fundamentally about values, and changes in attitudes and aptitudes... environmental education should provide content - in terms of the curriculum - and also allow students to be reflexive about their own ideas and behaviours ${ }^{5}$.

Indeed, the continuing promotion of ecotourism, conservation and research as an 'alternative' or 'green' development strategy since the 1980s has made Costa Rica an international success story, with national leaders and leading researchers largely attributing this success to the strategic use of education to create an environmentallyaware citizenry. Programmes are organised by a wide variety of actors with an interest in these issues. In the formal education sector, this includes the Ministry of Education as well as a number of privately-funded schools throughout the country. In addition, the Ministry of Environment promotes environmental learning throughout the national system of protected areas, while the country's many private conservation groups and NGOs coordinate a diverse range of educational initiatives for local community members and visitors. National media campaigns by state and private organisations, usually on television and radio, constitute a further set of public education initiatives ${ }^{6}$.

While the central aims of these programmes are often the same, however, perspectives and practices are far from uniform. The implementation of government education

\footnotetext{
${ }^{5}$ My translation, from the original Spanish.

${ }^{6}$ For a more detailed discussion of the national scene, see Blum (2007).
} 
policies in local schools, for instance, can be impacted by local economic circumstances and the demands of the labour market, by relationships between educators and the communities in which they work, and by access to resources. Equally, the kind of educational programmes provided by national parks or conservation areas varies greatly depending upon the goals of individual organisations (especially in terms of ideas of best practice in tourism management and conservation) as well as the nature of relationships between such protected areas and neighbouring communities (either with a history of conflict or of strong local support). Understanding how such issues play out in the particular social and economic contexts of individual communities is important to developing a more nuanced vision of the processes through which ideas and policies about environmental education are implemented.

\section{Environmental Education in Monteverde}

As a community, the Monteverde is as emblematic as a 'green' destination as the nation of Costa Rica itself, and it is an internationally recognised site for forest conservation, scientific research and ecotourism. It is one of Costa Rica's most popular tourist destinations, and attracts an estimated 200,000 visitors each year (MVI 2002), including researchers, conservationists, bird enthusiasts, international students and adventure tourists. In 1992, the annual economic impacts of the local tourism industry were estimated at US\$5 million for a regional population of approximately 4,000 inhabitants (Burlingame 2000: 376). The majority of the local population is thus economically dependent - either directly or indirectly - on the tourism industry, and work in the sector is often reliant on some knowledge of the local environment and conservation efforts. The importance of conservation and ecotourism to the local economy, and the need for related skills for local employment, therefore make education about the environment of particular significance locally.

Indeed, environment and education are on the agendas of most, if not all, community organisations, including schools, conservation organisations, local businesses, and government agencies. Due to their highly visible educational role, however, local schools are often the focal point for environmental education initiatives and reforms. In 2002-2003, there were two government primary schools, a state secondary school, and three privately-funded schools (offering a range of primary and secondary levels) offering classes for the community's children. Environmental education was provided in all these schools, although to varying degrees and often in quite different ways.

Ethnographic research in two of these local schools - the government secondary school and one privately-funded school - in particular yielded detailed accounts of schools' and individual educators' struggles to implement environmental education policies both due to the complex nature of the concept of environmental education itself and because of on-going resource constraints. Furthermore, these two cases illustrate that while many schools in the community struggle with similar problems in terms of implementing environmental education, the relationships between individual schools and the wider community alternately provided both support and further constraint in these attempts. The complex nature of these positionings and their multiple impacts on programming, in turn, point to a need to conduct research on environmental education which moves beyond analysis of happenings within the 
Citation: Blum, N. (2008) Ethnography and environmental education: understanding the relationships between schools and communities in Costa Rica. Ethnography and Education, 3(1): 33-48.

school walls and also attends to the social, economic and political dynamics of the communities in which schools are located.

\section{Colegio Técnico Profesional de Santa Elena}

The state secondary school, or Colegio, in Monteverde is located along the main road on a hill above the commercial centre of the village of Santa Elena. The property includes two long, narrow, one-storey concrete breeze-block buildings which contain the main office, teachers' lounge, computer lab, library and classrooms. Beyond these is a small concrete football pitch, a large area used for agricultural projects, a pasture with cattle, a large chicken house, and an artificial pond constructed for an experimental fish farming project. During school hours, the site is filled with the noisy presence of its several hundred students, ranging in age from thirteen to eighteen. All students are required to wear uniforms - dark blue trousers or skirts, light blue, button-down tops decorated with the school emblem, and dark shoes - as they are in state schools around the country. Nevertheless, the atmosphere is relaxed, with teachers and students working together in classrooms and chatting informally in the corridors.

Like all other secondary schools in the country, students at the Colegio take classes in the basic subjects (ranging from languages, mathematics and natural sciences to religion, civics, industrial arts, music and physical education) during all four years of study. On top of this, students also take on courses in a chosen specialisation for the final two years. Colegios across the country offer either academic specialisations (focussing on science and the humanities) or technical programmes (concentrating on industrial, business or agricultural topics). The governing board of each school is authorised to decide which is the most appropriate programme for local circumstances, and then to apply for approval from the Ministry of Education. The Colegio in Santa Elena, however, is one of only four schools in Costa Rica which offers a specialist programme in ecotourism (turismo ecológico).

The ecotourism programme was first introduced on-site in 2002. Topically, it encompasses five broad subject areas: environmental education, environmental management, ecology, ecotourism, and English. The tenth grade curriculum, for example, allows for 80 student contact hours in 'environmental education', 40 hours on 'environmental contamination', 40 hours on 'environmental legislation' and 80 hours on 'rural tourism' over the course of the academic year. Overall, the specialisation requires intensive study of ecology (and especially the identification and memorisation of locally endemic species of flora and fauna), discussion of environmental concerns and management, and the development of an understanding of national and international environmental legislation and the agencies involved in their promotion.

The curriculum is heavily oriented towards teaching very specific content, especially in the natural sciences, which is then assessed through challenging, content-based national examinations. At the same time, the curriculum documents are strongly framed in terms of teaching concepts, values and ethics. The intended goals for the 'environmental education' component in the tenth grade curriculum being used in 2003, for example, stated: 
Citation: Blum, N. (2008) Ethnography and environmental education: understanding the relationships between schools and communities in Costa Rica. Ethnography and Education, 3(1): 33-48.

'This sub-area centres on the development of students' interest in the management and control of situations that bring about environmental deterioration. Through an understanding of the causes and effects of specific concerns such as contamination, inadequate planning, exploitation of resources, and the impacts of production activities, among others, it will stimulate the search for solutions which promote conservation of the environment and sustainable resource use... Students should be converted from simple observers to critical thinkers and protagonists of change.' 7

This values-led educational philosophy echoes the language found in national discourses and policy statements, and is commonly reflected by government school teachers. One teacher that expressed such sentiments was Teresa Ramírez, a teacher in the ecotourism specialisation who was born and raised in Monteverde, and who was regarded within the school and the wider community as a dedicated educator ${ }^{8}$. She told me that she believed her role as a teacher was to foster both the intellectual and personal development of her students. In order to do this, she planned assignments that provided students with time to think and work on their own:

The thing is, students can always sit down and read a book to learn the facts about something, but they can't learn values that way. Values can only be taught through conversation and interaction. If the students aren't being taught values at home, then it is even harder. I prioritise conversation and teaching values over the contents of the curriculum whenever I have the opportunity. ${ }^{9}$

At the same time, Teresa and her colleagues at the Colegio often struggled to provide lessons of this type for a number of reasons, including time constraints and on-going limits to teaching resources provided by the government. Teaching strikes are a common occurrence, for example, and can paralyze the school system for extended periods. During the time of this research two separate strikes were called by the powerful national teaching unions, leading to cancellation of classes for almost six weeks of the academic year. This made it particularly difficult for teachers to cover all of the required content of the national curriculum in order to prepare their students for end-of-year exams.

Local teachers also recounted difficulties in finding sufficient or appropriate teaching materials. Many classrooms I visited during the fieldwork year were largely empty of learning materials such as textbooks, notebooks, or posters, and many contained only a chalkboard and a set of antique student desks. Even basic resources such as chalk and paper were often so scarce that teachers paid for them out of their own wages.

In the ecotourism programme specifically, Teresa told me that she had encountered real difficulties in trying to find appropriate resources to teach the required units on local ecology. The curriculum requires students to be able identify a large number of scientifically important birds, reptiles, amphibians, land mammals, insects and plants for national exams. The school did not have textbooks for either students or teachers

\footnotetext{
${ }^{7}$ My translation, from the original Spanish.

${ }^{8}$ All names have been changed, to protect confidentiality.

${ }^{9}$ My translation, from the original Spanish.
} 
to consult, however, and there is no public library in the region. Teresa instead relied on a single field guide to teach about birds, another for reptiles, frogs, and insects, and yet another for plants.

Struggles to provide ecotourism students with knowledge about such topics are especially significant locally because teachers, parents and students know that opportunities for local employment depend heavily upon on it. It was for this reason that the Colegio's ecotourism programme was specifically designed to train students to take up work as nature guides, environmental educators or protected area staff such as guards, administrators, or management - the kinds of jobs commonly viewed by residents as the most stable and profitable local employment opportunities.

The Colegio did, however, receive help in providing these skills and training for students through close ties with the Santa Elena Reserve (Reserva Bosque Nuboso Santa Elena). The small (310 hectare) reserve was originally leased to the Colegio by the Costa Rican state in 1983 for use in agricultural projects. By 1990, the plot's severe climate and infertile soils had led to the discontinuation of agricultural production, and the area was re-developed as a community-run ecotourism destination (see Wearing 1993). The project's leaders hoped it would support the financiallystrapped Colegio as well as provide training opportunities for students. A committee within the Colegio itself is charged with managing the Reserve, with additional support from members of the local community.

In 2002, this important educational link between the Colegio and the Reserve was maintained by Luis, an environmental education co-ordinator employed by the Reserve. His work involved leading workshops and seminars, and guiding students on visits to the Reserve for hikes on the trails or to work as volunteers. Teachers at the school relied heavily on him to assist with the development of lessons on local ecology and endemic species, and would regularly make requests for information, ideas and workshops for their students. Teachers involved in the ecotourism specialization were especially grateful for this support because it filled existing (and on-going) gaps in resources, training and expertise.

The link between the Colegio and the Reserve also continued to be important to many students after they completed their studies. Experience volunteering in the Reserve was useful in gaining formal employment there or in other local conservation areas, for example, and helped students to develop local contacts and to understand how the ecotourism industry operates locally. A content-based exam on local flora and fauna was also required to obtain membership in the local nature guides association, and both formal studies and work in the Reserve were likely to enhance the possibility of membership and to lead to gainful employment.

Another key skill which students required for future employment in the local ecotourism industry, however, was fluency in English. This was partly related to the high demand for English-language tour guides, and also because so much local research and conservation was conducted by English-speaking residents and visitors. This demand for English-language skills, combined with the sometimes severe financial constraints and resource limits experienced within state schools, had 
therefore led some local parents to seek educational opportunities for their children within local private schools.

Private education did undoubtedly provide some practical advantages, but implementation of environmental education can be as problematic there as it is in state schools. Like their state school counterparts, local private school teachers were heavily impacted by the curriculum content and assessment requirements imposed by the government education bureaucracy. In addition, the social positioning of individual private schools within local and national contexts often served to further complicate the negotiation of definitions and practices of environmental education.

\section{The Cloudforest School}

One particularly good example of the complicated relationships involved in environmental education in local private schools is provided by the case of the Cloudforest School (also the Centro de Educación Creativa, or CEC). According to the school's own historical account, it was established in 1991 by five local families who were concerned by overcrowding and what they perceived to be the low educational standards of local state schools. The founding group included North American and Costa Rican residents, members of the local Quaker community, and a locally-resident North American biologist. It was at the suggestion of the biologist, who had been conducting research in the region since 1973 before settling there permanently with his family in 1980, that the school adopted its environmental education orientation.

In the early years, the school had no building, so classes were conducted in the homes of local parents. In 1992, a 42-hectare forest property was purchased with a loan from The Nature Conservancy. Since that time, the school has rapidly expanded with support from the non-profit Cloudforest School Foundation based in Tennessee (USA) as well as supplementary funds from individual programme grants (largely from US foundations) and a range of local fundraising activities. By 2003, the school's infrastructure included four sets of buildings for classroom and office space, hiking trails, ornamental gardens, organic vegetable and herb gardens, and a greenhouse, all situated on a hilltop outside of the centre of Santa Elena. In 20022003, the school's total enrolment had also grown to include 173 students ranging in age from pre-school through secondary school.

The school's mission statement outlines its overall goals in the following way:

'Centro de Educación Creativa is a bilingual, environmentally-oriented school in the multi-cultural cloud forest community of Monteverde/Santa Elena, Costa Rica. Students are mostly native Costa Ricans who will inherit responsibility for preserving the surrounding cloud forest and making sustainable development a reality. We intend to develop students' skills to do this effectively and, through a bilingual immersion approach, the voice to do so on a global scale. Centro de Educación Creativa promotes environmental awareness and responsibility by incorporating environmental education into every segment of its interdisciplinary curriculum. We will encourage the development of well-rounded persons by addressing the spiritual, mental and physical needs of each individual, while fostering an awareness and 
Citation: Blum, N. (2008) Ethnography and environmental education: understanding the relationships between schools and communities in Costa Rica. Ethnography and Education, 3(1): 33-48.

knowledge of community and world affairs and their affect on our environment.'

The mission statement thus provides an outline for a child-centred educational philosophy and emphasises the importance of environmental learning in the school. While many of the school's teachers, administrators, governing board and parents told me that they strongly supported this educational ethic, I also frequently witnessed intense discussions over curriculum content and the practicalities of implementing it. These disagreements can be traced to the complicated nature of relationships between residents involved in the school and their sometimes conflicting definitions of environmental education, as well as to the school's relationships to the wider community and the state education bureaucracy.

One of the main reasons for these on-going negotiations was the fact that, as of 2003, the school had no formally agreed definition for environmental education. This had led to a variety of understandings and approaches to environmental learning by those involved in implementing it in the school. Unlike their state school counterparts who shared a common set of definitions and goals through the standardised state curriculum (although this was of course also subject to interpretation) - teachers at the Cloudforest school had, in the absence of an agreed definition, organised their classrooms according to their own interest in or commitment to certain topics, ways of teaching, or goals for environmental learning. The range of instructional activities used at the school also ranged widely, from teaching taxonomies in the classroom to taking walks in the forest, working in gardens, or completing community service projects.

One teacher, a North American resident who had taught at the school since its early years, defined environmental education as an opportunity for students to have a 'magical' experience in which they learn to feel connected to the natural world:

'What we [the school] feel is important is the concepts of science, of social studies, those kinds of things, rather than just information. Not "how many miles long is the river?" but "where does it come from?", "where does it go?", "what is the cycle of water?"... those kinds of things... it's about understanding the cycles [of life] but making it magical.... Having imagination play a part in it.'

This approach contrasts strikingly, however, with the definitions and goals for environmental education offered by other educators at the school. The school's land manager, José, for instance, provided weekly lessons for classes in each grade level, but his interactions with students centred on teaching them practical skills such as how to germinate plant and tree seedlings, to manage a garden, or to compost. Rather than taking place in a classroom, José's lessons were located in the school greenhouse, gardens, or forested areas, with the specific learning activities dependent on the age and knowledge-level of each student group. Younger students were given responsibility for small-scale projects such as collecting decaying plant material from the forest floor to serve as an organic base for seed germination. Older students, on the other hand, were responsible for overseeing reforestation efforts on degraded areas of the school property. Interestingly, José argued that what he did was not 
Citation: Blum, N. (2008) Ethnography and environmental education: understanding the relationships between schools and communities in Costa Rica. Ethnography and Education, 3(1): 33-48.

environmental education - or at least not in the sense that others at the school spoke about it:

The environmental education co-ordinator deals with all the theoretical ideas and the curriculum requirements. What I do is the practice. I believe that this is the most important part for children to learn - conservation, reforestation, recycling, rescuing plants and, very importantly, soil conservation. ${ }^{10}$

As would be expected, this diversity of ideas and practices sometimes resulted in conflict and sometimes in collaboration between educators at the school. Furthermore, these tensions also played out in the school's relationships to the wider community and the national education infrastructure.

Like their state school counterparts, for instance, educators at the Cloudforest School faced limitations on what they believed was ideal educational practice as a result of the Ministry of Education's national curriculum and assessment requirements. Although the school originally operated according to its own (rather informal) curriculum guidelines, administrators were later forced to adopt a version of the Ministry's curriculum and examination requirements in order to receive state accreditation. Teachers complained, however, that the demands of preparing students for national exams often left little or no time for other kinds of teaching or activities. This was even true of environmental education, many teachers told me, despite the school's stated mission to create environmentally-aware students. As a result, discussions amongst staff and board members at the school frequently centred on the need to balance the teaching of environmental education concepts with preparing students for exams. According to the director:

'The tests really constrain us quite a bit. There's testing in sixth, ninth and eleventh grade, so luckily the elementary is pretty free until sixth grade. There are some topics we touch on in other grades that will be on the exam. But then in sixth grade it's like, 'OK, we need to teach some of this curriculum' because the test is... it's not like an ITBS [Iowa Test of Basic Skills] test that tests whether you can read and write and do basic math. It actually tests content. Science is taught that way too. It's a specific set of facts they need to know. So it's not conceptual, which is hard because that's really contrary to our educational beliefs. We really try to teach the "deep concepts" and not just memorising facts.'

The state system's focus on teaching content was also strongly criticised by other educators at the school. As one teacher commented:

'The educational programmes here [in Costa Rica] are very much... you copy off the board, and that's how you teach something. In fact, I was at one of these workshops with other educators from the region, and the speaker was telling them about how important the students' notebooks are. Those are the official record of what was taught, so every lesson should have the date on the top and a lesson plan of what is being taught that day, before their notes are in there. And that was the official record of what happened that day. And we

${ }^{10}$ My translation, from the original Spanish. 
Citation: Blum, N. (2008) Ethnography and environmental education: understanding the relationships between schools and communities in Costa Rica. Ethnography and Education, 3(1): 33-48.

were just like, 'Well, we don't really have those... Not everything we do is in the notebook'. You know, [whispered] 'We do stuff that's not in the notebook.' It's a very different way of thinking about education.'

Such perceived differences in perspective on the role of education and its best practice have had significant impacts on relationships and opportunities for collaboration between the school and other community groups, individuals, and state agencies, especially in terms of environmental education.

In some cases, however, perceptions of these different perspectives were as much the result of a lack of communication between educators as they were a statement about actual differences in educational practice. Many private school teachers in the community (many of whom were newly-resident US citizens), for example, were largely unaware of the strong transformative element of the state's educational philosophy and environmental education curriculum, either because of the linguistic and social divisions within the community, or their short-term residence in the region.

Equally, just as teachers at the Cloudforest School sometimes critiqued teaching methods in the state school system, educators in state schools - as well as other community members - often described the Cloudforest School as an elite institution for 'gringo' children. This perception was not necessarily based in fact, however, as the school struggled with its own limited budget and staffing problems, and its teachers earned significantly less than their state-school colleagues. Furthermore, although more than half of the teaching staff were either experienced teachers or recently qualified teaching graduates recruited from the United States, approximately $90 \%$ of the student body during the 2002-2003 school year were Spanish-speaking Costa Ricans ${ }^{11}$. Furthermore, these students were not from the most privileged local families, as nearly $60 \%$ of them received need-based grants from the school.

The perception of the school as an 'elite' or 'gringo' institution nevertheless had noticeable impacts on its relationships with other community organisations and individuals. Whereas the Colegio had a strong and beneficial relationship with the Santa Elena Reserve, for example, the Cloudforest School had relatively little connection with other local organisations and relied instead on largely international (mainly US) sources of support. Unfortunately, this lack of communication and collaboration with other local organisations seemed to further reinforce the perception of it as an 'elite' institution, and also to somewhat undermine the school's attempts to engage with the wider local community about environmental learning.

At the same time, these international linkages served the school and some of its students quite well. In past years, for example, funds were raised to send students to study in the US for one year. The school's bilingual curriculum also provided students from Spanish-speaking homes with an opportunity to learn English (indeed, the

\footnotetext{
${ }^{11}$ It would be a vast oversimplification of the situation to strictly divide the community into Costa Rican and foreign residents, however. Local identities are quite complicated due to the region's long history of settlement. A number of local residents who claim both Costa Rican and North American identities, for example, were born in the community and are descended from the original group of North American Quaker settlers or from foreign researchers who have settled permanently in the community. In this case, I use the term 'Costa Rican students' to refer to students whose parents are Costa Rican nationals themselves and whose first language is Spanish.
} 
majority of students I spoke with were fluent in both languages), which was likely to improve their chances of employment significantly either in Monteverde or elsewhere in Costa Rica. International visitors and school partnering arrangements provided further opportunities for interaction with other individuals and organisations with an interest in education and environmental management. Teachers and students also maintained strong relationships with local scientific researchers, a number of whom were members of the school's management board, and who helped support the school either through personal donations of time and money, or through their connections with international (US) funders with an interest in the environment and education.

\section{Conclusions}

As is shown by the case of these two schools in Monteverde, issues around education and environmental knowledge are constantly debated, practiced, defined and redefined by multiple actors both within schools and with reference to wider local contexts. The very particular ways in which these individual schools were located in social and economic networks, however, resulted in a range of both benefits and limitations on the implementation of environmental education programmes. Students at the Colegio, for example, had access to specialist training as nature guides and environmental educators, and could count on significant support from the Santa Elena Reserve. Their association with the Colegio and the Reserve also provided them with strong connections to the local ecotourism industry, and therefore to potential employers. Their counterparts at the Cloudforest School, on the other hand, did not have such strong relationships with local organisations, but did have greater access to international funding and to locally-important English-language learning which potentially increased their future employment opportunities in other ways.

Despite such differences, however, schools in Monteverde also shared a number of concerns about the appropriate content and implementation of environmental education, especially in light of the limitations imposed by the state education bureaucracy, and on-going problems of access to sufficient teaching and financial resources, and the demands of parents and local employers. Educators in both schools were engaged in active, on-going discussion about how to find a balance between providing students with the knowledge which would help them to succeed in formal education and the skills for future life and employment, as well as instilling appropriate social values and an awareness of local and global environmental issues. These pedagogical concerns were further complicated by each schools' financial limitations and their particular economic and social positions in the community. As the discussion highlighted, each of the schools experienced these discussions and concerns in very different ways.

By using ethnographic methods to highlight these similarities and differences, the focus of the research extended beyond description and analysis of activities or policy implementation in a single school, and was able to highlight the impacts on environmental education which are the result of the social and economic relationships between educators and the wider communities in which they work. It also demonstrated that the style of environmental education implemented in a community may be as much a reflection of locally available resources and training, and the needs and perspectives represented within a community, as it is of educators' or schools' commitments to a specific educational philosophy. In so doing, the work suggests that 
in order to better understand the complex, socially-embedded nature of environmental education, research is needed which further explores the links between educational actors and the contexts where they work.

\section{References}

Bernard, R. (1988) Research Methods in Cultural Anthropology. (London, Sage)

Blum, N. (2007). Environmental Education in Costa Rica: Building a framework for sustainable development?, International Journal of Educational Development, Available online: http://dx.doi.org/10.1016/j.ijedudev.2007.05.008.

Blum, N. (2006) The Social Shaping of Environmental Education: Policy and Practice in Monteverde, Costa Rica. Unpublished PhD Thesis, University of Sussex.

Booth, J. (1998) Costa Rica: Quest for Democracy (Boulder, Westview Press).

Boza, M. (1993) Conservation in Action: Past, present and future of the National Park System of Costa Rica, Conservation Biology, 7(2), 239-247.

Burlingame, L. (2000) Conservation in the Monteverde Zone: Contributions of conservation organisations, in: N. Nadkarni and N. Wheelwright (Eds.) Monteverde: Ecology and Conservation of a Tropical Cloud Forest pp. 351-388 (Oxford, Oxford University Press).

Dillon, J., Kelsey, E. and Duque-Aristizábal, A.M. (1999) Identity and Culture: Theorising emergent environmentalism, Environmental Education Research, 5(4), 395-406.

Evans, S. (1999) The Green Republic: A Conservation History of Costa Rica. (Austin, University of Texas Press).

Fischel Volio, A. (1987) Consenso y Represión: Una Interpretación Socio-Política de la Educación Costarricense (San José, Editorial Costa Rica).

González Gaudiano, E. (1999) Otra Lectura a la Historia de la Educación Ambiental en América Latina, Tópicos en Educación Ambiental, 1(1), 9-26.

Gough, N. (1996) Virtual Geography, Video Art and the Global Environment: Postmodernist possibilities for environmental education research, Environmental Education Research, 2(3), 379-390.

Ham, S. (1992) Environmental Interpretation: A Practical Guide for People with Big Ideas and Small Budgets (Golden, North American Press).

Hammersley, M. and Atkinson, P. (1995) Ethnography: Principles in Practice (London: Routledge).

Janzen, D. (ed.). (1983) Costa Rican Natural History (Chicago, University of Chicago Press).

Jaritz, K. (1996) Environmental Education in Teacher Training: A case study at seven German colleges and universities and its outcome, Environmental Education Research, 2(1), 51-62.

Jickling, B. (1992) Why I Don't Want My Children to be Educated for Sustainable Development, Journal of Environmental Education, 23(4), 5-8.

Kollmuss, A. and Agyeman, J. (2002) Mind the Gap: Why do people act environmentally and what are the barriers to pro-environmental behaviour?, Environmental Education Research, 8(3), 239-260.

Kwan, T. and Lidstone, J. (1998) Understanding Environmental Education in the People's Republic of China: A national policy, locally interpreted, Environmental Education Research, 4(1), 87-98. 
Citation: Blum, N. (2008) Ethnography and environmental education: understanding the relationships between schools and communities in Costa Rica. Ethnography and Education, 3(1): 33-48.

Lozt-Sisitka, H. (2004) Environmental Education Research and Social Change: Southern African perspectives, Environmental Education Research, 10(3), 291295.

McKeown, R. and Hopkins, C. (2003) EE $\neq$ ESD: Defusing the worry, Environmental Education Research, 9(1), 117-128.

MEP [Ministerio de Educación Publica]. (2002) Los Temas Transversales en el Trabajo de Aula. Curriculum document. San José, Costa Rica: Ministerio de Educación Publica.

MVI [Monteverde Institute] and USF Globalization Research Center. (2002) 'Encuesta de Desarrollo: Encuesta para residencias'. Unpublished survey data. Monteverde, Costa Rica: Monteverde Institute.

Palmer, J. (1998) Environmental Education in the 21 $1^{\text {st }}$ Century: Theory, Practice, Progress and Promise (London: Routledge).

Palmer, J., Suggate, J., Robottom, I. and Hart, P. (1999) Significant Life Experiences and Formative Influences on the Development of Adults' Environmental Awareness in the UK, Australia and Canada, Environmental Education Research, 5(2), 181-200.

Pellegrini Blanco, N. (2002) An Educational Strategy for the Environment in the National Park System of Venezuela, Environmental Education Research, 8(4), 463-473.

Sauvé, L. (1996) Environmental Education and Sustainable Development: A further appraisal, Canadian Journal of Environmental Education, vol. 1, 7-33.

Stables, A. (2001) Who Drew the Sky? Conflicting assumptions in environmental education, Environmental Education Research, 33(2), 245-256.

Sterling, S. (2001) Sustainable Education: Re-visioning Learning and Change, Schumacher Briefing Number 6 (Totnes: Green Books Ltd).

UNCED. (1992) Agenda 21, The United Nations Programme of Action from Rio. New York: United Nations.

UNESCO-UNEP. (1976) The Belgrade Charter, Connect, 1(1) (Paris: UNESCO).

Wallace, D.R. (1992) The Quetzal and the Macaw: The Story of Costa Rica's National Parks (San Francisco, Sierra Club Books).

Wals, A. (1996) Back-alley Sustainability and the Role of Environmental Education, Local Environment, 1(3), 299-316.

Wearing, S. (1993) Ecotourism: The Santa Elena Rainforest Project, The Environmentalist, 13(2), 125-135. 